\title{
Application of tuned mass dampers in high-rise construction
}

\author{
Vyacheslav Teplyshev ${ }^{1, *}$, Alexey Mylnik ${ }^{1}$, Maria Pushkareva $^{1}$, Murad Agakhanov $^{2}$ and \\ Olga Burova $^{2}$ \\ ${ }^{1}$ Moscow Aviation Institute (National Research University), Volokolamskoe highway, 4, Moscow, \\ 125993, Russia \\ ${ }^{2}$ Moscow State University of Civil Engineering, Yaroslavskoye sh., 26, 129337 Moscow, Russia
}

\begin{abstract}
The article considers the use of tuned mass dampers in highrise construction for significant acceleration and amplitude of vibrations of the upper floors under dynamic wind influences. The susceptibility of people to accelerations in high-rise buildings and possible means of reducing wind-induced fluctuations in buildings are analyzed. The statistics of application of tuned mass dampers in high-rise construction all over the world is presented. The goal of the study is to identify an economically attractive solution that allows the fullest use of the potential of building structures in high-rise construction, abandoning the need to build massive frames leading to over-consumption of materials.
\end{abstract}

\section{Introduction}

The construction of high-rise buildings requires the attraction of advanced achievements in many fields of civil engineering and related sciences. In order to implement ambitious construction projects, that may become symbols of cities and countries, it is necessary to conduct works on the economic substantiation of construction, architectural design, site conditions, the choice of building materials, construction design, development of building technology and its safe and durable operation.

The specialists of each of the indicated directions face unusual for their practice challenges when they deal with such projects. In this case, a large number of tests in the design of high-rise buildings fall to the share of engineers who develop building structures, whereas the situation is often aggravated by unfavorable conditions of the construction site, related to possible intense wind and seismic effects.

\section{Materials and Methods}

One of the effective examples of controlling the vibrations in the floors of a high-rise building, which is subject to intense wind, is the Taipei 101 skyscraper in Taipei, Taiwan. A specially designed Tuned Mass Damper (TMD) deals with damping of low-frequency vibrations and a reducing their amplitudes during typhoons, especially on the upper floors.

*Corresponding author: teplyshev@tbnenergo.com 
These solutions for monitoring the amplitude-frequency response of buildings are still relatively rare, but interest in them is growing, as with a competent approach it is possible to build high-rise buildings in regions where it is usually associated with increased expenses to ensure sufficient rigidity of the load-bearing frames and stumbles upon an undesired maximum height, dictated by considerations of comfort.

The use of tuned mass dampers is advisable, including construction in areas, that are common to high-rise buildings, since it provides an opportunity to achieve qualitatively better operational and economic characteristics. However, additional research is required for the extended application of such a vibration damping system. Swayings of a high-rise structure under wind influence can quickly lead to its destruction if a resonance occurs and the amplitude reaches excessive values. However, usually the swayings are not so vigorous as to damage the structure of a skyscraper, but can cause serious discomfort to people on the upper floors.

For modern light high-rise buildings, monitoring horizontal swayings of floors to ensure sanitary requirements can be a greater challenge than the need to ensure the structural strength of buildings. Acceleration is the natural factor of all dynamic influences. The horizontal force felt by people is directly proportional to the horizontal acceleration, which is impressed upon the structure, according to Newton's first law. According to the research, the most sensitive people are able to feel acceleration from one thousandth of the acceleration due to gravity. Detailed results of the study on the susceptibility of people to accelerations in high-rise buildings are given in Table 1.

Table 1. People's susceptibility to accelerations in high-rise buildings.

\begin{tabular}{|c|c|l|}
\hline & Acceleration, $\mathbf{~ m} / \mathbf{s}^{2}$ & \multicolumn{1}{c|}{ Effect } \\
\hline 1 & $<0.05$ & People do not feel the swayings \\
\hline 2 & $0.05-0.10$ & $\begin{array}{l}\text { - sensitive people may notice an acceleration } \\
\text { - dangles sway slightly }\end{array}$ \\
\hline 3 & $0.10-0.25$ & $\begin{array}{l}\text { - most people feel the swayings } \\
\text { - swayings disturb desk work } \\
\text { - long-term exposure may cause motion sickness }\end{array}$ \\
\hline 4 & $0.25-0.40$ & $\begin{array}{l}\text { - desk work becomes very difficult or unbearable } \\
\text { - foot travel is still possible }\end{array}$ \\
\hline 5 & $0.40-0.50$ & $\begin{array}{l}\text { - people strongly feel the swayings } \\
\text { - walking becomes difficult } \\
\text { - standing people find it difficult to balance }\end{array}$ \\
\hline 6 & $0.50-0.60$ & $\begin{array}{l}\text { Most people are very uncomfortable to move; they cannot walk } \\
\text { normally }\end{array}$ \\
\hline 7 & $0.60-0.70$ & $\begin{array}{l}\text { All people are very uncomfortable to move; people cannot walk } \\
\text { normally }\end{array}$ \\
\hline 8 & $>0.85$ & Objects begin to fall; people can be injured \\
\hline
\end{tabular}

The requirements of standards in Russia are consistent with the results of the research described above: in the normative document [1], the maximum permissible horizontal acceleration of the floor is limited to $0.08 \mathrm{~m} / \mathrm{s}^{2}$ with a wind load equal to $70 \%$ of the normative value of its pulsation component.

Understanding, that it is not enough for normal operation of high-rise buildings in conditions of severe storms and hurricanes to meet the requirements of the dynamic comfort of buildings in their design, came to engineers after analysis of the operational experience of the numerous skyscrapers. However, there are only three relevant factors that can be controlled at the design stage: height, shape and mass, which affects the dynamic response of the building [2]. 
The limitation of excessive vibrations can be achieved in three ways: by increasing the stiffness to reduce the period of vibrations, by controlling the mass and by special design of the building's shape to improve its aerodynamic properties.

The listed above traditional approaches to design are applicable only in certain areas, behind which serious questions about the physical feasibility of projects, their cost and aesthetic qualities arise.

Thus, the attention of practicing engineers turned to various damping devices, as a means to damp the vibrations of structures under wind influences [3].

For reference, a set of possible approaches to reduce wind-induced vibrations in buildings is given in Table $2[4,5]$.

Table 2. Possible approaches to reduce wind-induced vibrations in buildings.

\begin{tabular}{|l|l|l|l|}
\hline \multicolumn{1}{|c|}{ Approach } & \multicolumn{1}{|c|}{ Type } & \multicolumn{1}{|c|}{ Method and goal } & \multicolumn{1}{c|}{ Comments } \\
\hline $\begin{array}{l}\text { Aerodynamic } \\
\text { design }\end{array}$ & Passive & $\begin{array}{l}\text { Improvement of aerodynamic } \\
\text { properties to reduce aerodynamic } \\
\text { coefficients }\end{array}$ & $\begin{array}{l}\text { Corners with chamfers or } \\
\text { holes; holes in the core }\end{array}$ \\
\hline $\begin{array}{l}\text { Structural } \\
\text { design }\end{array}$ & Passive & $\begin{array}{l}\text { Increasing the mass of the building to } \\
\text { reduce the effect of wind pressure }\end{array}$ & Increase of cost \\
\cline { 3 - 4 } & & $\begin{array}{l}\text { Increase stiffness and natural vibration } \\
\text { frequency }\end{array}$ & $\begin{array}{l}\text { Adding bonds, increasing } \\
\text { wall thicknesses and } \\
\text { column stiffness }\end{array}$ \\
\hline $\begin{array}{l}\text { Supplementar } \\
\text { y damping }\end{array}$ & Passive & $\begin{array}{l}\text { Use of materials and design joints with } \\
\text { additional dissipative properties to } \\
\text { increase the damping of the structure }\end{array}$ & $\begin{array}{l}\text { SD, SJD, FD, } \\
\text { VED, VD, OD }\end{array}$ \\
\cline { 3 - 4 } & $\begin{array}{l}\text { Adding supplementary mass to increase } \\
\text { the level of damping }\end{array}$ & TMD, TLD \\
\cline { 2 - 4 } & Active & $\begin{array}{l}\text { Generation of inertia forces to soften } \\
\text { dynamic reactions }\end{array}$ & AMD, HMD, AGS \\
\cline { 3 - 4 } & $\begin{array}{l}\text { Generation of aerodynamic forces to } \\
\text { reduce aerodynamic coefficients }\end{array}$ & $\begin{array}{l}\text { Screws, turbines, } \\
\text { aerodynamic elements }\end{array}$ \\
\cline { 3 - 4 } & Change in stiffness to avoid resonance & AVS \\
\hline
\end{tabular}

The tuned mass damper is a device consisting of a mass attached to the main structure by means of a spring and a damping element. A layout view on the damper in the Taipei 101 building is shown in Figure 1. 


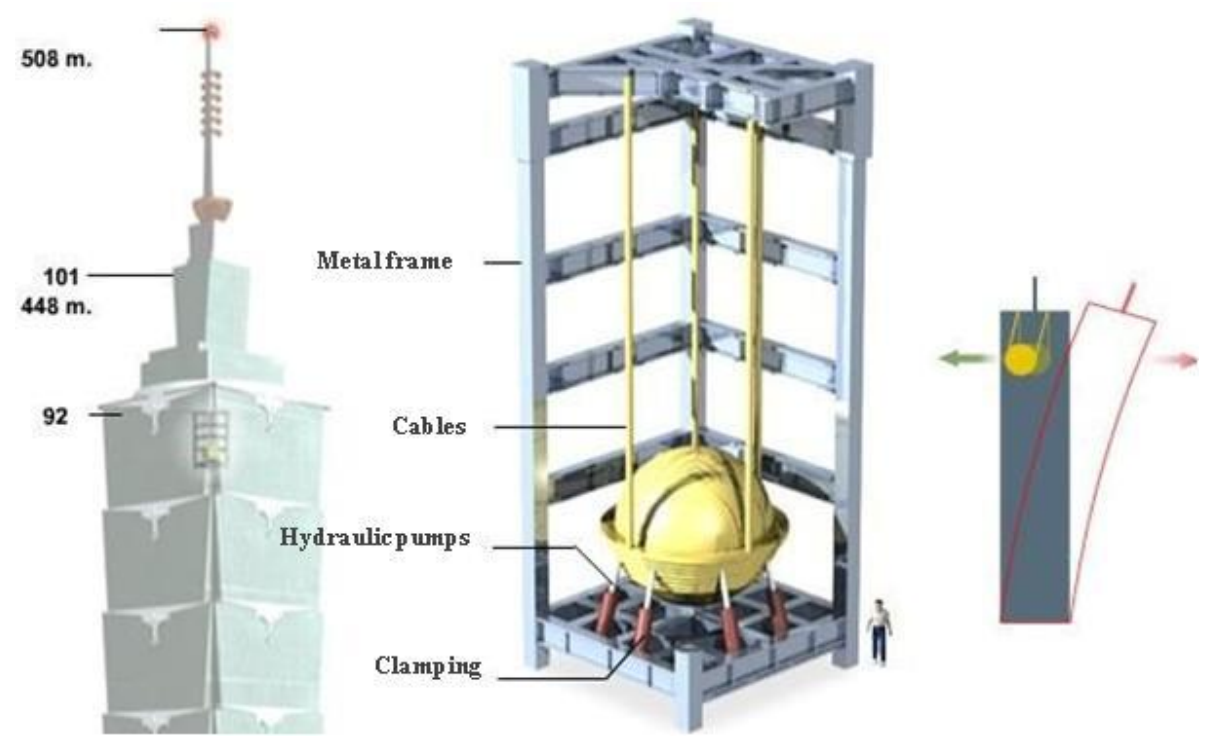

Fig. 1. Damper in Taipei 101 building.

\section{Results}

The spring can be performed by devices that ensure the connection of the mass with the structure of stiffness $k$. In the present work tuned mass dampers are considered, where the mount plays the role of spring, connecting the bearing structures and the mass and forming a pendulum.

In the calculations, a finite-element system is used, which is similar to the pendulum with equivalent stiffness $k d$ and damping $c$.

The applicability of this analogy is justified by the following formulas.

The equation of motion in the horizontal direction corresponds the following formula:

$$
T \cdot \sin b+W d / g \cdot\left(\mathrm{u}^{11}+u d^{11}\right)=0
$$

where, $W_{d}-$ is the weight of tuned mass damper, $\mathrm{H} ; T-$ tension load in the mount, N.

At small values of the force $T$, the following simplification is possible:

$$
T=L \cdot \sin b=L \cdot b ; \quad T=W d
$$

Then the equation of motion reduces to the following:

$$
m_{d} \cdot u_{d}+W_{d} / L \cdot u_{d}=-m_{d} \cdot u^{11}
$$

Then equivalent stiffness $k_{d}, \mathrm{~N} / \mathrm{m}$ is

$$
k d=W d / L
$$

The length of the pendulum mount is chosen to ensure the optimal adjustment of the tuned mass damper: the vibration frequency of the mass should correspond to a certain frequency of the natural vibration of the structure. The mass should vibrate in reverse phase to the structure and damping (dispersion of the vibration energy through special damping devices) should be possible.

A special advantage of using mounts as the formation of a "spring" is the possibility of constant adjustment of the stiffness of the damper under the structure, because its dynamic characteristics can vary significantly depending on the running load imposed or changes in 
the stiffness of its bearing elements and node points occurred due to some external influences $[6,7]$.

As damping devices, the elements of viscous friction (oil buffers) are commonly used. These devises are made as cylinders with liquid, where perforated or loosely adhering pistons move. When some motion is imparted to a piston of the oil buffer, a viscous frictional force arises in the buffer, which is proportional to the speed of the piston. At the same time, the constancy of viscous properties of oils or other liquids used in buffers should be ensured. Thus, each swaying of the mass dissipates part of vibration energy of the structure and reduces the amplitudes and accelerations of its vibrations. The general dynamic design of the system with a damper is shown in Figure 2.

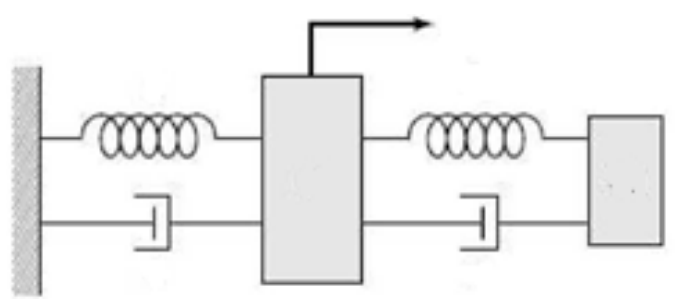

Fig. 2. General dynamic design of the system with a damper.

The mass itself usually has a relatively small mass. The use of tuned mass damper with mass equal to $1-5 \%$ of the modal mass of the structure in the form of vibrations tuned to is considered optimal.

There are several high-rise buildings with tuned mass dampers in the world. Information on some of them is summarized in Table 3.

Table 3. Several buildings with tuned mass dampers.

\begin{tabular}{|l|l|l|l|l|}
\hline Name and height & $\begin{array}{l}\text { City or } \\
\text { country }\end{array}$ & $\begin{array}{l}\text { Number of } \\
\text { dampers }\end{array}$ & $\begin{array}{l}\text { Year of } \\
\text { erection }\end{array}$ & $\begin{array}{l}\text { Own frequency } \\
\text { and/or } \\
\text { mass of damper }\end{array}$ \\
\hline Taipei 101, 508 m & Taipei & $1+2$ & 2004 & $730 \mathrm{t} ; 2$ to $4.5 \mathrm{t}$ \\
\hline Trump World Tower, 262 m & New York & 1 & 2001 & $600 \mathrm{t}$ \\
\hline Canadian National Tower, 533 m & Toronto & 1 & 1976 & $18 \mathrm{t}$ \\
\hline Akita Tower, 112 m & Akita & 1 & 1994 & $0.41 \mathrm{~Hz}$ \\
\hline Sydney Tower, 305 m & Sydney & 1 & 1980 & $0.1 \mathrm{~Hz} ; 0.5 \mathrm{~Hz} / 370 \mathrm{t}$ \\
\hline City Corp Center, 278 m & New York & 1 & 1978 & $0.16 \mathrm{~Hz} / 370 \mathrm{t}$ \\
\hline John Hancock, 241 & Boston & 2 & 1977 & $0.14 \mathrm{~Hz} / 2300 \mathrm{t}$ \\
\hline
\end{tabular}

\section{Discussions}

The structures of high-rise buildings usually have relatively high deformability in horizontal directions, which causes significant acceleration and vibration amplitude of their upper floors under dynamic wind influences.

Therefore, the significant issue of their design is to ensure the requirements for a comfortable stay of people, consisting in limiting the amplitudes and acceleration of vibration in the upper floors of structures. These requirements are provided in civil engineering standards all over the world, including Russia, Europe and the United States. 


\section{Conclusion}

The practical importance of this study is to identify an economically attractive solution that allows the most complete use of the potential of building structures in the high-rise construction, abandoning the need to build massive frames, leading to over-consumption of materials and providing excessive strength. This work contributes to a deeper introduction of the concept of tuned mass dampers into the engineering discourse and to widening of the possible geography of their use in high-rise construction.

\section{References}

1. U.Y. Kuvshinov, Theoretical Basics of Indoor Microclimate Providing. Scientific publication (Moscow, Edition of Building University Association,2007)

2. V.G. Gagarin, V.A. Zemtsov, N. M. Igumnov, Roofing and Insulation Materials, 4, 4143 (2011)

3. A. U. Bezrukov, Microclimate of Dwelling Premises. Light Transmitting Constructions, 3 (2003)

4. P. Diachek, S. Makarevich, A. Zakharevich, D. Livansky, Vestnik MGSU, 7, 143-147 (2011)

5. M. Jevric, M. Romanovich, Procedia Engineering, 165, 1478 - 1482 (2016)

6. T. Simankina, M. Romanovich, O. Tsvetkov, MATEC Web of Conferences, 53, 01054 (2016)

7. T. Saknite, D. Serdjuks, V. Goremikins, L. Pakrastins, N.I. Vatin, Magazine of Civil Engineering, 64(4), 26-39 (2016) 